\title{
Development of a proteomic platform for EBV and KSHV serological screening
}

\author{
Leyao Wang ${ }^{1 *}$, Dasheng Zheng ${ }^{1}$, Jian Zhu², Gangling Liao', Crystal Woodard ${ }^{2}$, C-J Chiou', Gary Hayward ${ }^{1,3}$, \\ Prashant Desai ${ }^{1,3}$, Richard Ambinder ${ }^{1,3}$, Heng Zhu²,3, S Diane Hayward ${ }^{1,3}$ \\ From $12^{\text {th }}$ International Conference on Malignancies in AIDS and Other Acquired Immunodeficiencies \\ (ICMAOI)
}

Bethesda, MD, USA. 26-27 April, 2010

In the context of HIV infection, there is an increased susceptibility to EBV- and KSHV-associated malignancies. Evaluating a possible role for specific humoral responses to individual viral proteins in the control of viral load and prevention of EBV or KSHV related disease development in this population has been hampered by the limited availability of suitable screening reagents.

We have developed a protein array platform that can be utilized for EBV and KSHV serological screening. The array consists of EBV and KSHV proteins printed onto glass slides. All eighty-four EBV open reading frames and eighty-six KSHV open reading frames were cloned into bacterial vectors and the inserts validated by DNA sequencing in both directions. Authenticated inserts were transferred to a yeast vector that expresses proteins as $\mathrm{N}$ terminal GST-fusions. Seventy-nine EBV proteins and eighty-one KSHV proteins were successfully purified from yeast. First-generation EBV/KSHV protein arrays have been printed with these proteins plus a variety of control proteins that include GST, and human IgG, IgM, and IgA.

Glycosylation of viral proteins may affect immunogenicity. To evaluate this aspect, EBV and KSHV virion glycoproteins are being expressed in insect cells modified with the human glycosylation machinery. Once purified, these proteins will be added to the EBV/KSHV protein arrays.

The ability to compare serological responses to the complete repertoire of individual EBV and KSHV encoded proteins should provide new insight into B cell mediated immune regulation of these viruses.

\footnotetext{
* Correspondence: Iwang7@jhmi.edu

'Department of Oncology, Johns Hopkins School of Medicine, Baltimore, MD, USA

Full list of author information is available at the end of the article
}

\section{Acknowledgements}

This article has been published as part of Infectious Agents and Cancer Volume 5 Supplement 1, 2010: Proceedings of the $12^{\text {th }}$ International Conference on Malignancies in AIDS and Other Acquired Immunodeficiencies (ICMAOI).The full contents of the supplement are available online at http://www.biomedcentral.com/1750-9378/5?issue=S1.

\section{Author details}

'Department of Oncology, Johns Hopkins School of Medicine, Baltimore, MD, USA. ²Department of Pharmacology, Johns Hopkins School of Medicine, Baltimore, MD, USA. ${ }^{3}$ Sidney Kimmel Comprehensive Cancer Center, Johns Hopkins School of Medicine, Baltimore, MD, USA.

Published: 11 October 2010

\section{doi:10.1186/1750-9378-5-S1-A18}

Cite this article as: Wang et al:: Development of a proteomic platform for EBV and KSHV serological screening. Infectious Agents and Cancer 2010 5(Suppl 1):A18.
Submit your next manuscript to BioMed Central and take full advantage of:

- Convenient online submission

- Thorough peer review

- No space constraints or color figure charges

- Immediate publication on acceptance

- Inclusion in PubMed, CAS, Scopus and Google Scholar

- Research which is freely available for redistribution

Submit your manuscript at www.biomedcentral.com/submit
C Biomed Central 